\title{
A new species of Heterolepisma from Barrow Island (Zygentoma: Lepismatidae)
}

\author{
Graeme Smith \\ Australian Museum, 6 College Street, Sydney, New South Wales 2010, Australia. \\ Email: le_gbsmith@optusnet.com.au
}

\begin{abstract}
The silverfish fauna of Barrow Island is discussed and Heterolepisma parva sp.nov. is described from extensive material collected mostly in pitfall traps or Winkler sac leaf litter samples.
\end{abstract}

KEYWORDS: Thysanura, taxonomy

\section{INTRODUCTION}

Extensive biological survey work on Barrow Island commencing in 2006 (Callan et al. 2011) collected about 1500 silverfish which were sent to the author for sorting to morphospecies. All except one belonged to the family Lepismatidae, a family which has received very little attention in Australia, with the most recent review of the Australian fauna by Womersley in 1939. The collection proved to be quite rich in species with at least 10 morphospecies (selected examples Figures 1-8), one of which (nominally Acrotelsella devriesiana group) certainly includes more than one species and quite probably several.

The majority of specimens collected during this survey work belong to the genus Acrotelsella Silvestri (Figures 1-4). This genus is quite common in Australia, especially in hotter and drier regions. It is also known from South America, Africa, the Middle East, South-East Asia into China and various Pacific and Indian Ocean islands such as the Galapagos, Hawaii, Madagascar and the Seychelles. The author has collected many species in Australia and seen many more in museum collections, none of which can be confidently identified due to the complexity of the genus and the inadequate early descriptions. The genus requires a great deal of attention for a clear picture of the Australian fauna to be established. Ideally this morphological work should be accompanied by molecular studies to overcome the difficulties of intraspecific variation associated with the lack of a defined adult stage (silverfish may moult more than twenty times during their life and continue to moult after reaching sexual maturity e.g. Lepisma saccharina Linnaeus (see Laibach 1952) and the superficial damage that occurs between moults such as lost scales and setae.

The Barrow Island material also contained a single male specimen belonging to the enigmatic endemic genus Anisolepisma Paclt, 1967 (Figure 5), previously only known from a single female collected at Northampton, WA by the 1905 Michaelsen \& Hartmeyer Hamburg University South Western Australia expedition (Silvestri 1908). Originally suspected as being conspecific with Anisolepisma hartmeyeri (Silvestri), re-examination of the holotype of the latter has shown the two to be separate species. These and other species will be described, along with a revision of the genus in a separate work (Smith \& Mendes, in preparation).

At least two other genera are represented which are probably new; one belonging to the subfamily Ctenolepismatinae and represented by several specimens (Figure 6) and the other from an extremely small (ca. $2 \mathrm{~mm}$ ) but probably mature, slightly damaged female from the subfamily Lepismatinae (Figure 7). The introduced, cosmopolitan Ctenolepisma longicaudata Escherich was later collected within buildings on the island.

Work outside the initial biosurvey project collected a large female Nicoletiid of the genus Trinemura Silvestri from a subterranean habitat. Its very long ovipositor distinguishes it from other described species of Trinemura however a mature male would be required to adequately describe the species' morphology.

Surprisingly, no representatives of the Atelurinae, were found among the material provided. Silverfish 


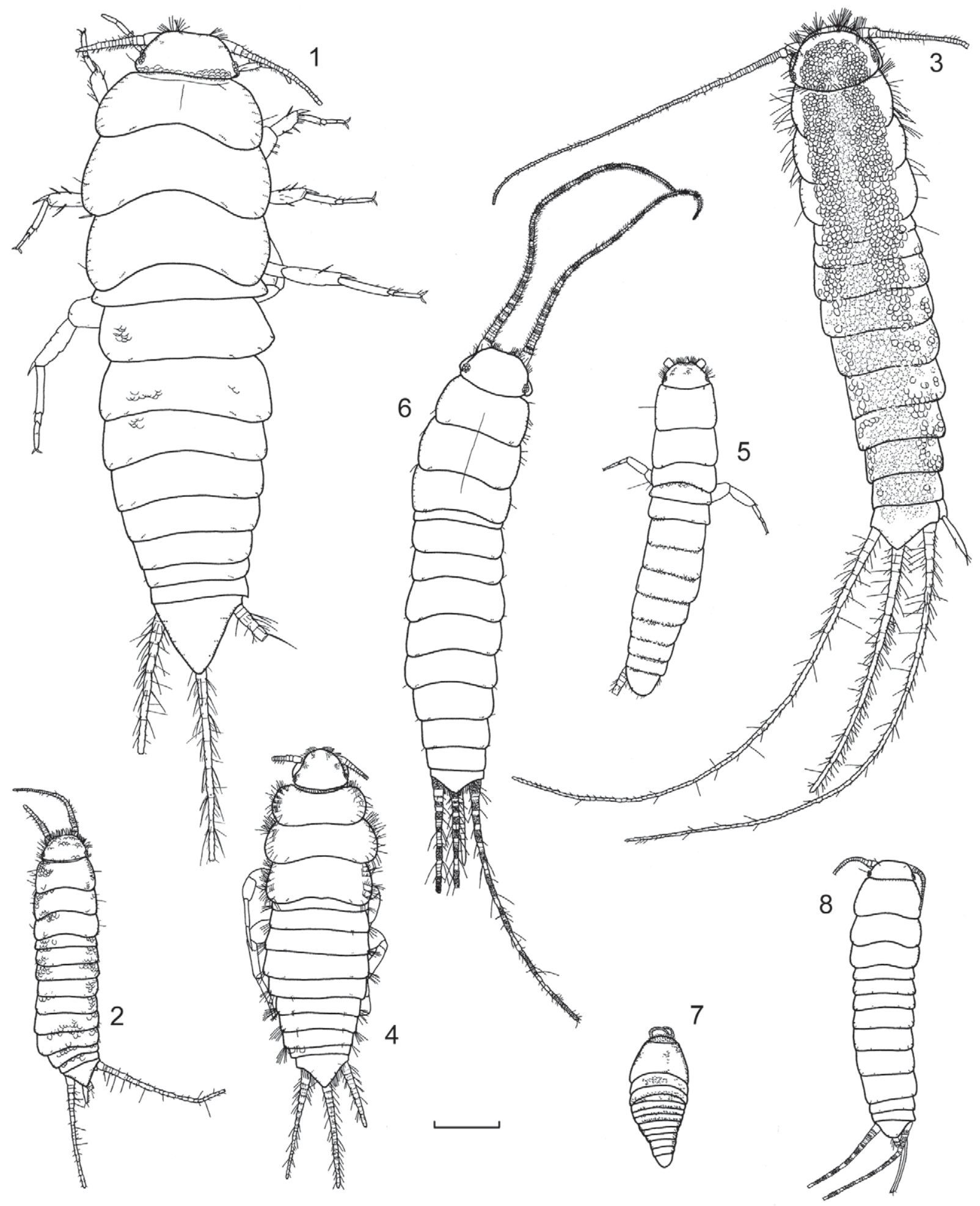

FIGURES 1-8 Selected Barrow Island morphospecies, all adult, most with antennae and terminal filaments incomplete and only some scales shown: 1, Acrotelsella (devriesiana group); 2, Acrotelsella sp.; 3, Acrotelsella sp.; 4, Acrotelsella sp.; 5, Anisolepisma sp.; 6, Ctenolepismatinae, genus unknown; 7, Lepismatinae, genus unknown; 8, Heterolepisma parva sp. nov. (holotype). All to same scale, scale bar: $1 \mathrm{~mm}$. 
of this subfamily are, to a greater or lesser extent, inquilines with ants or termites. Given the large numbers of ant species collected and the excavation of termites nests during the survey work, their presence on the island would be expected, suggesting there is possibly a sampling issue with this subfamily. Many inquilines rarely travel outside the nest with the worker ants and so would have little chance of being caught in pitfall traps. Being safely ensconced in the host nest they would have avoided suction sampling and most are surprisingly agile and quickly disappear from view when the nest is disturbed.

Finally, large numbers of a single species of the genus Heterolepisma Escherich, 1905 were collected in many of the sampled localities. It is a comparatively small species and not much more than half the size of other Heterolepisma species so far described and its description is the subject of this paper.

Escherich (1905) created the genera Heterolepisma (for Lepisma pampeana Silvestri, 1902 and L. andina Silvestri, 1902, both from Argentina) and Isolepisma (for his new species I. trisetosa from Indonesia). The two genera differed from each other in a number of minor ways including body shape, length of urotergite $X$ and the degree rather than the pattern of the chaetotaxy. Stach (1933) reviewed Escherich's arrangement, in light of the 10 additional species described in the intervening years, concluding that there was no justification for maintaining Heterolepisma and Isolepisma as separate genera. He selected Heterolepisma as the generic name for all species previously included in these two genera without specifically nominating which of the two species described by Escherich was to be the type species. Paclt (1967) lists Lepisma pampeana Silvestri, 1902 as the type species. In the meantime, Tillyard (1924) had created the genus Notolepisma for his new species $N$. zealandica from New Zealand. Wygodzinsky (1961) examined topotypical material of this species (the holotype apparently very poorly preserved), correcting some errors in the description and making Notolepisma a new synonym of Heterolepisma.

Heterolepisma is considered by various authors (e.g. Mendes 1991, Irish 1990) to be the most plesiomorphic genus of the Lepismatidae. It is a large widespread genus with a mostly southern distribution with many described species occurring in the Australian region. It is also found in South America, on several Pacific and Indian Ocean islands (Wygodzinsky 1967) and as far north as the southern islands of Japan (Uchida 1944 and 1968). It is not common in Africa but records exist from Angola and Mozambique (Mendes 1993) and $H$. exacta (Silvestri, 1918) was described from Tanzania. In total some 18 species are described, mostly inadequately.

Silvestri (1908) described the first Australian species of Heterolepisma from south-western Western Australia with H. stilivarians, H. kraepelini, $H$. michaelseni and H. hartmeyeri (the latter now the type species of Anisolepisma Paclt, 1967). Womersley (1939) presented a translation of Escherich's description slightly modified to include Silvestri's Australian species, commenting that the four endemic species described by Silvestri (1908) differ only in the shape of the metasternite. He reports finding $H$. stilivarians to be not uncommon under the loose bark of Eucalypts in the Mount Lofty ranges SA, records $H$. michaelseni at Sou'-West River on Kangaroo Island and not uncommonly under eucalypt bark at Glenunga, SA and of frequently taking $\mathrm{H}$. kraepelini from under eucalypt bark in the foothills of the Mount Lofty Range, near Adelaide and at Murray Bridge, SA as well as Trevallyn in Tasmania. Womersley (1942) also described $H$. howensis from Lord Howe Island, but Wygodzinsky (1961) suggested that $H$. howensis may just be a population of $H$. zealandica. Many undescribed species have recently been collected from all Australian states and more species are represented in various museum collections around Australia. Given the now fairly inadequate nature of these early descriptions, it would be worthwhile re-examining Womersley's material, challenging the identifications and redescribing Silvestri's original material. This is however beyond the scope of this paper, which will only describe the species common on Barrow Island and discuss its morphology in comparison to those species already described.

\section{SPECIMEN SELECTION AND PREPARATION}

Four tubes containing larger specimens were selected as the type series. The preservation of the bristles in this material was generally poor however the insertion points are clearly visible in dissected and slide mounted material. All specimens referred to in the description are deposited with the Western Australian Museum, 49 Kew Street, Welshpool, Western Australia 6106. Some of the numerous other specimens of this species collected on Barrow Island (not included in the type series) have been deposited in the entomological collection of the Australian Museum in Sydney, while the rest will be returned to Curtin University, Kent Street, Bentley, Western Australia 6102.

Measurement data of whole specimens in alcohol were taken using a 10/100 scale in the 10x ocular 
of an Olympus CHT stage microscope. Specimens were placed in a Petri dish one third filled with black sand so that the part to be measured could be oriented close to horizontal. Head width was measured between the outer edges of the eyes not from the margins of the mouthparts; head and body length (from front of head to posterior margin of urotergite $\mathrm{X}$ ), thorax (length between anterior and posterior margins along the mid-line, width at widest point of each notum), abdominal segment (width between widest points), antennae (length from base of scape to tip), pedicel and scape (length between joint with adjacent articles along midline of view, width at widest point), articles of maxillary and labial palps (length along midline from articulation with adjacent articles or to apex width at widest point, cerci and median dorsal appendage from base to tip, tibia length between articulations with adjacent articles along midline of view, width at widest point, stylets from base to tip (excluding apical spines), ovipositor from posterior margin of urosternite VII to apex. The length and width of urotergite $X$ and the processes of urosternite IX were measured only from slide material to ensure that curved surfaces had more or less flattened out before measurement.

Specimens were dissected under an Olympus SZ61 stereomicroscope and mounted on slides using Tendeiro solution. In general the head and thorax were mounted on one slide and the abdomen on a second slide. Efforts were made to line up the urosternites and urotergites in two lines from front to back however movement of the sclerites within the mounting fluid results in this ordering only being approximate. Drawings were made with the aid of an Olympus CX31 binocular microscope fitted with a U-DA drawing attachment.

All locality grid co-ordinates are quoted using the datum WGS84 (50). Roman numerals are used to indicate abdominal segment number. In addition the following abbreviations are used:

$\begin{array}{ll}\text { HW } & \text { Head width (mm) } \\ \text { H+B } & \text { Head and body length }(\mathrm{mm}) \\ \text { L/W } & \text { Length to width (ratio) } \\ \text { PIT } & \text { Pitfall trap collection } \\ \text { PI, PII, PIII } & \begin{array}{l}\text { Legs of prothorax, mesothorax } \\ \text { and metathorax respectively }\end{array} \\ \text { SA } & \text { South Australia } \\ \text { WA } & \text { Western Australia } \\ \text { WAM } & \text { Western Australian Museum } \\ & \text { specimen number } \\ \text { WSC } & \text { Winkler sack collection }\end{array}$

\section{SYSTEMATICS}

\author{
Family Lepismatidae Latreille, 1802
}

Subfamily Heterolepismatinae Mendes, 1991

Heterolepisma Escherich, 1905

Heterolepisma Escherich, 1905: 63.

Isolepisma Escherich, 1905: 61.

Notolepisma Tillyard, 1924: 241.

TYPE SPECIES

Lepisma pampeana Silvestri, 1902 by subsequent designation.

Heterolepisma parva sp. nov.

Figures 8-65

urn:Isid:zoobank.org:act:E532A628-4231-4D7E-823F06349F19DF81

\section{MATERIAL EXAMINED}

\section{Holotype}

Australia: Western Australia: + (HW 0.78), Barrow Island (NO7a 332008, -7697340), 1 May 2007, S. Callan, K. Edwards, WSC (WAM E83506) on two slides (head and thorax, abdomen).

\section{Paratypes}

Australia: Western Australia: 1 (HW 0.80), same collection data as holotype (WAM E83507) in $80 \%$ ethanol; 1 ( $\mathrm{HW}$ 0.78), same data as holotype (WAM E83508) in 80\% ethanol; 1 o (HW 0.70), same collection data as holotype (WAM E83509) on two slides; 1 đ (HW 0.73), Barrow Island (GP2 339462, -7699882), 25 September 2006, S. Callan, R. Graham WSC (WAM E83510) on two slides; 1 ઈ (HW 0.65), Barrow Island (NO5b 334218, -7692088), 1 May 2007, S. Callan, K. Edwards, WSC (WAM E83511) in 80\% ethanol; 1 ( $\mathrm{HW}$ 0.75), same collection data as previous (WAM E83512) in 80\% ethanol; 1 specimen (sex unknown) (HW 0.80), only head, thorax, abdominal segments $\mathrm{I}-\mathrm{V}$, same collection data as previous (WAM E83513) on one slide; 1 ऽ (HW 0.73), same collection data as previous (WAM E83514) on two slides; 1 ( $(\mathrm{HW} 0.79$ ), same collection data as previous (WAM E83515) in $80 \%$ ethanol; 1 우 (HW 0.70), Barrow Island (CC2 337659, -7697280), 15 March 2006, S. Callan, R. Graham (WAM E83516) on one slide; 1 ㅇ (HW 0.73), same collection data as previous (WAM E83517) on two slides; 1 ㅇ (HW 0.73), same collection data as previous (WAM E83518) on one slide. 


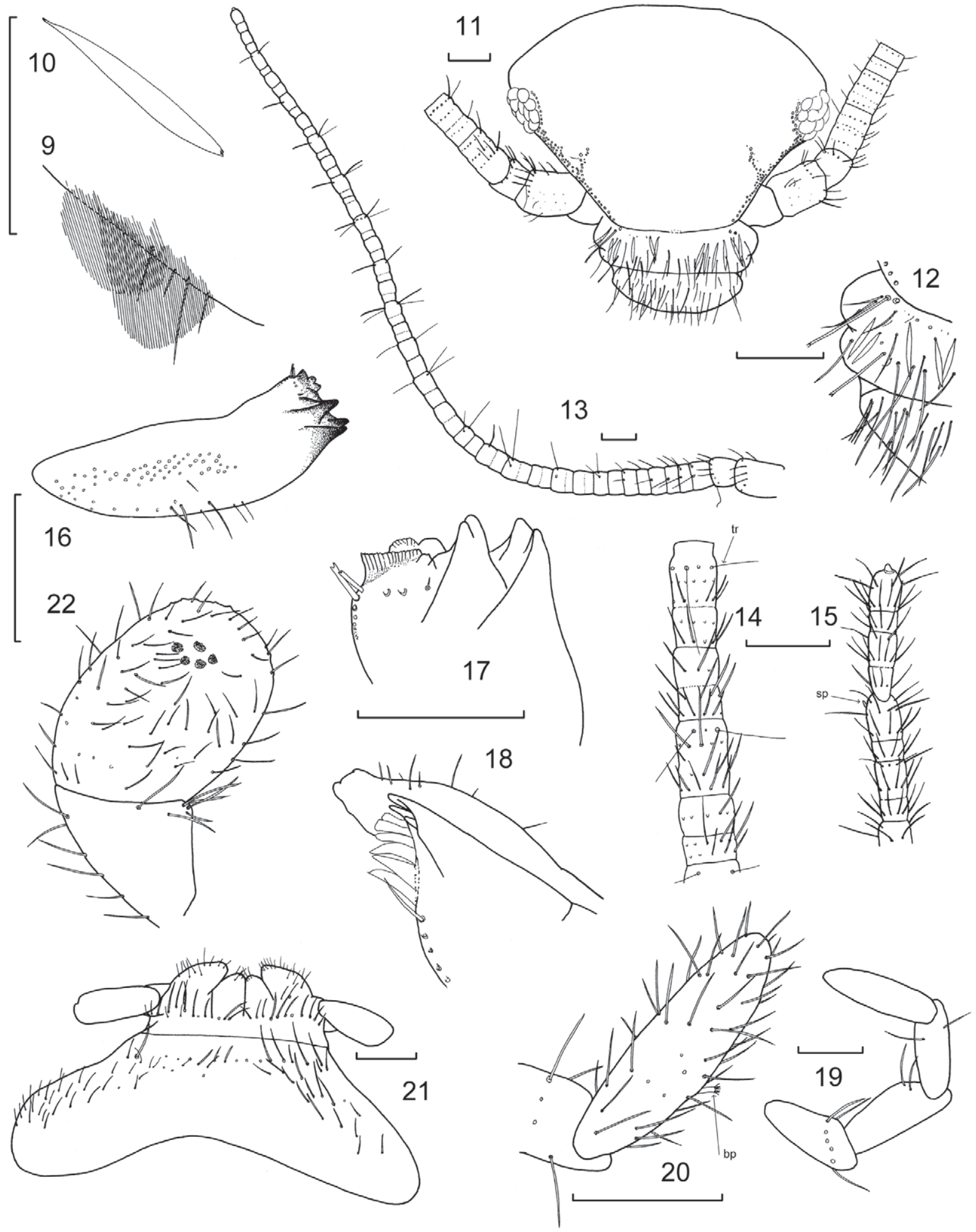

FIGURES 9-22 Heterolepisma parva sp. nov., holotype o (WAM E83506) unless otherwise indicated by specimen number: 9, scales of urosternite VIII (WAM E83509); 10, lanceolate scale of femur; 11, head; 12, half of clypeus; 13, antenna (WAM E83514); 14, 11th and 12th articles of antenna with one trichobothria indicated (tr); 15, 26th and 27th article of antenna (WAM E83514) with one sensory point indicated (sp); 16, mandible; 17, id., enlargement of incisor and molar areas; 18, maxilla, enlargement of lacinia and galea; 19, maxillary palp (only slightly stronger setae shown); 20, id., apical article showing one of the branched papillae (bp); 21, labium with two most distal articles of both palps missing; 22, ultimate and penultimate article of labial palp. All scale bars $=0.1 \mathrm{~mm}$. 


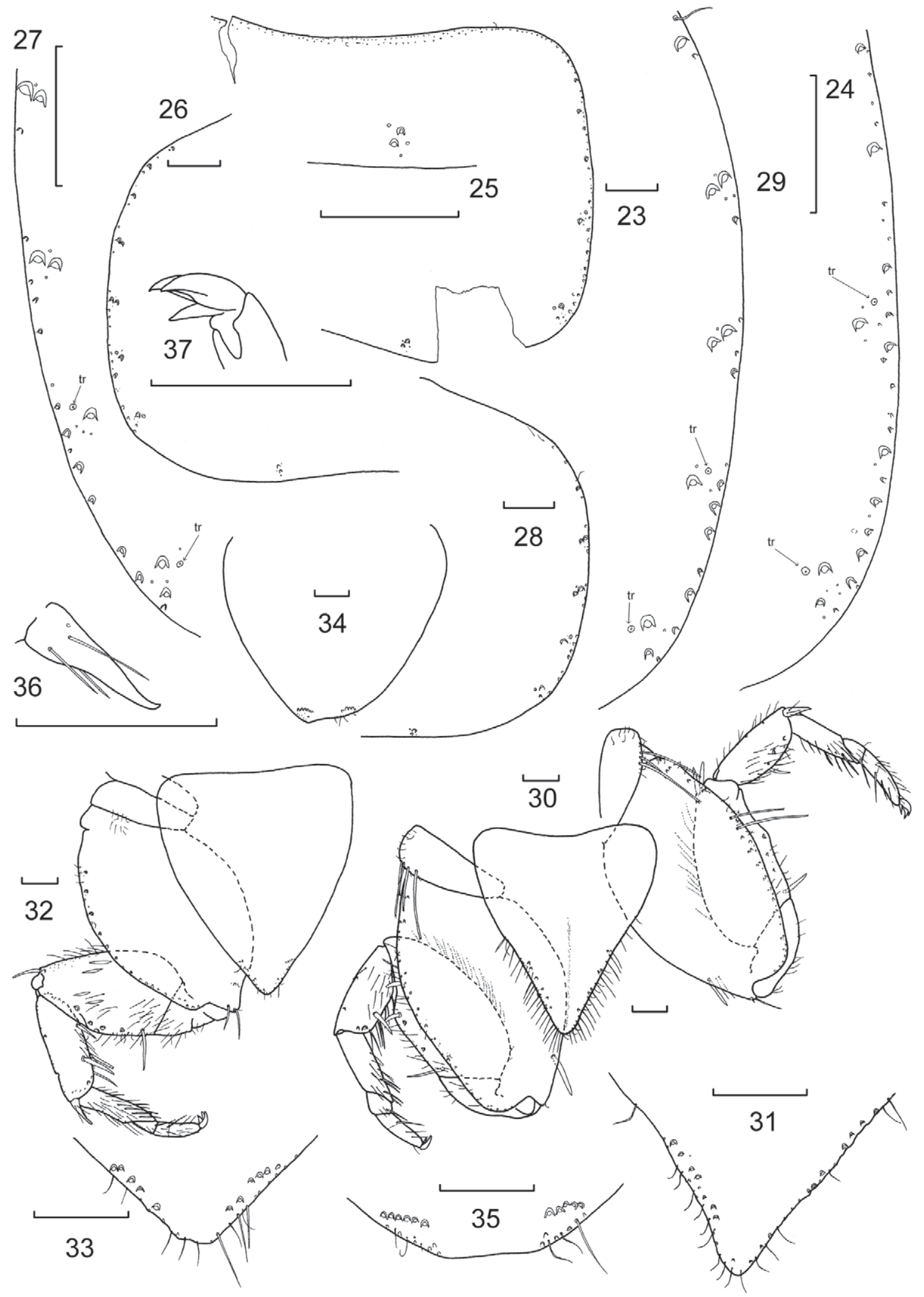

FIGURES 25-37 Heterolepisma parva sp. nov., holotype q (WAM E83506) unless otherwise indicated by specimen number: 23, pronotum, right half; 24, id., posterolateral margin and trichobothrial areas $(\operatorname{tr}=$ trichobothria); 25, id., detail of right posterior comb; 26, mesonotum, left half; 27, id., posterolateral margin and trichobothrial areas; 28, metanotum, right half; 29, id., posterolateral margin and trichobothrial areas; 30, legs and sternum of prothorax (WAM E83513); 31, detail of distal combs of prosternum; 32, mesothoracic leg and sternum; 33, detail of distal combs of mesosternum; 34 , metasternum; 35, id., detail of distal combs (WAM83513); 36, apical spur of tibia of PII; 37, pretarsus PII. All scale bars $=0.1 \mathrm{~mm}$. 


\section{Other material examined in detail}

\section{(not included in type series)}

Australia: Western Australia: 1 juvenile $\widehat{0}$ (HW 0.58), Barrow Island (GP2 339462, -7699882), 15 March 2006, S. Callan, R. Graham, PIT (WAM E83519) on one slide; 1 juvenile $\hat{\alpha}$ (HW 0.68), same collection data as previous (WAM E83520) on two slides; 1 juvenile ${ }^{\lambda}$ (HW 0.53), same collection data as previous (WAM E83521) on one slide.

\section{DIAGNOSIS}

This species can be distinguished from other described species by its smaller size and a combination of other factors such as the presence of a medial comb on urosternite I, combs of multiple macrochaetae on urosternites II-VII, the $2+2$ combs on urotergites I and VIII and the number of stylets (two pairs in females and only one pair in males) as well as the presence of lanceolate scales.

\section{DESCRIPTION}

Body size: up to $4.4 \mathrm{~mm}$ (ठ) 4.5 (ㅇ), no obvious size difference between sexes; maximum head width $0.80 \mathrm{~mm}$; thorax: length up to $1.48 \mathrm{~mm}$ (or 0.26-0.35 times $\mathrm{H}+\mathrm{B}$ ); width up to $1.15 \mathrm{~mm}$ (in most specimens widest at the mesonotum); antennae damaged in all specimens measured, maximum preserved length $3.55 \mathrm{~mm}$ (or > 0.70 times $\mathrm{H}+\mathrm{B}$ ); terminal filaments damaged in all specimens measured, maximum preserved length of cerci 2.15 $\mathrm{mm}$ (or > 0.55 times $\mathrm{H}+\mathrm{B}$ ); maximum preserved length of median dorsal appendage $1.98 \mathrm{~mm}$ (or $>0.44$ times H+B). Small species (Figure 8) with thorax only slightly wider than or equal to anterior abdominal segments, subsequent abdominal segments gradually narrower.

Hypodermal pigment: brown or slightly purple, pigment laterally on head especially surrounding the eyes, weaker pigment extending along bush behind antennal bases and very weakly across head in some specimens, a light band crossing distal half of clypeus, pedicel and scape as well as rest of flagellum uniformly lightly pigmented, maxillary palp with dense pigmentation in articles two, three and four but less in the ultimate and basal articles, labial palp with pigmentation on articles two and especially three, ultimate article with pigment around all margins but weaker on central surface, thoracic tergites with slight pigmentation anterolaterally and across anterior margin and its setal collar, legs with pigmentation on all articles except distal three tarsal articles, pigment stronger along external margins of coxa, posterior margin of trochanter, over most of femur but stronger distally and posteriorly, tibia and first tarsal article fairly darkly and uniformly pigmented, coxites IX with light pigmentation especially around stylet insertion, stylets pigmented in basal half, cerci and median dorsal appendage with strong dark rings of pigmentation, the darker areas getting increasingly longer distally. Some individuals do show greater or lesser levels of pigment intensity, especially juvenile specimens where pigment can be almost completely lacking.

Scales: shape and pattern uncertain; most scales on slide material can only be seen when viewed from their sides suggesting that they are almost clear and practically invisible when lying flat in a slide preparation, the few major scales seen are clear, rounded with very fine parallel rays that do not surpass the distal margins (Figure 9); thinner lanceolate scales, or perhaps better described as flattened widened setae as they appear to lack ribs and are often raised up rather than lying against the surface (Figure 10), at least on clypeus, coxae and probably tibia. Those on clypeus and tibia seem to be easily lost during preparation of the slide and were not visible on all specimens.

Macrochaetae: mostly lost but those present smooth, bifid apically or simple and hyaline or slightly straw-coloured.

Head: wider than long (Figure 11), rows of macrochaetae along the lateral margins and up over the anterior two thirds of the eyes, well developed rows extending subperpendicularly to the margin from base of antennae; clypeus with numerous setae as well as several lanceolate scales (Figure 12); anterior margin glabrous except for three or four very small medial setae (or perhaps lanceolate scales as only insertion points remain), it is ambiguous as to whether these are on a small bulge of the clypeus or the anterior part of the frons. Rounded scales on top of head only. Eyes dark, composed of 12 ommatidia. Antennae incomplete in type series, longest existing antennae with at least 27 articles reaching to about two thirds $\mathrm{H}+\mathrm{B}$ (Figure 13); scape about twice as long as pedicel, articles from $3^{\text {rd }}$ with subapical trichobothria, articles from $11^{\text {th }}$ (Figure 14) show signs of subdivision which is distinct by the $16^{\text {th }}$ article, from the $20^{\text {th }}$ article each subarticle shows signs of further subdivision, a pattern which continues at least to the $27^{\text {th }}$ article (most distal retained article seen on specimen WAM E83514), the more distal articles with some, but not many, small rod-like sensillae (sensory points) near the apex of each article (Figure 15). Mandibles typical (Figures 16, 17) with well developed molar and incisor areas; a group of up to ten setae becoming more strongly bifurcated apically, shorter, thicker and apically flatted towards the molar area (although holotype 


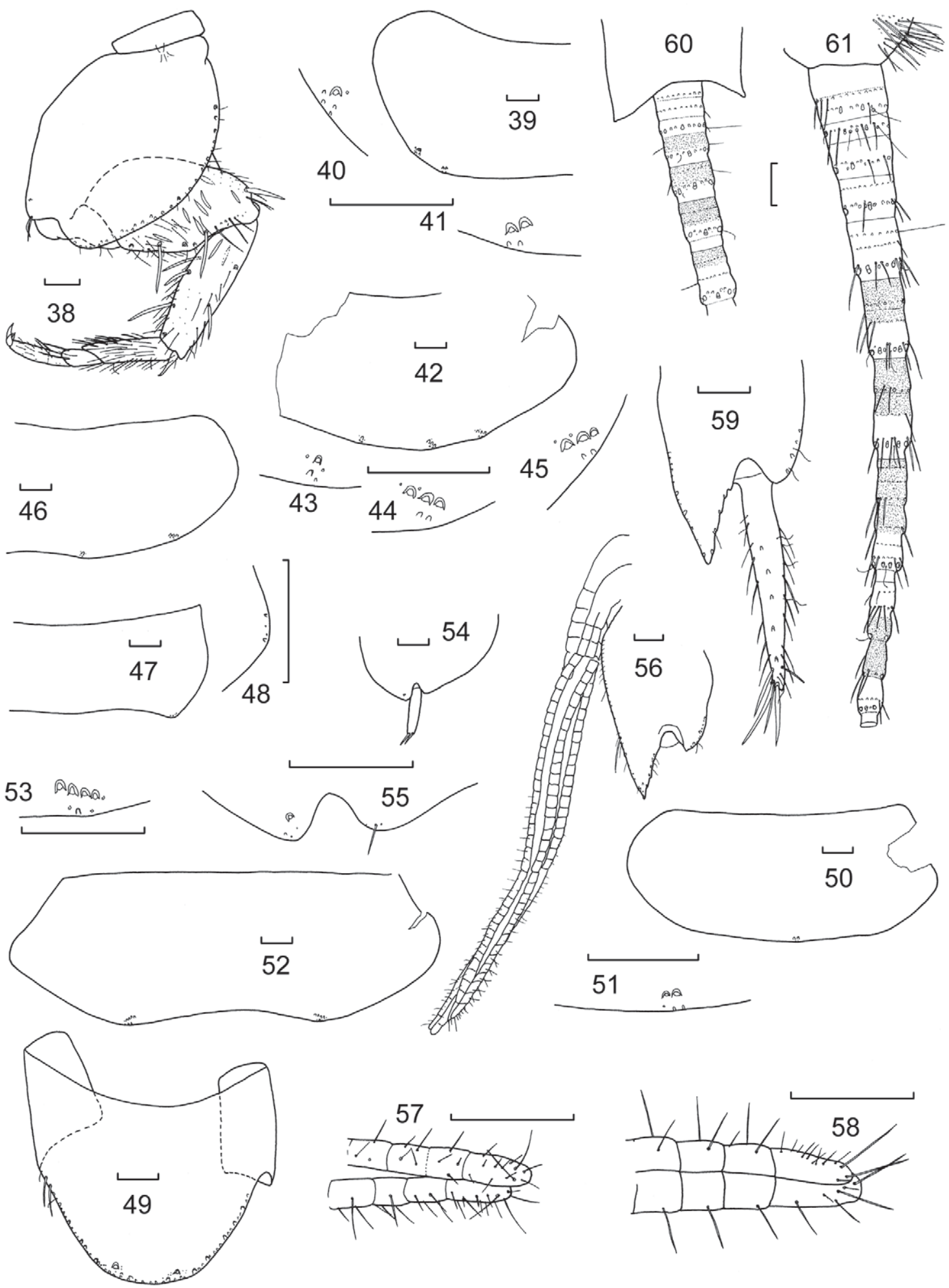

FIGURES 38-61 Heterolepisma parva sp. nov., holotype o (WAM E83506) unless otherwise indicated by specimen number: 38, metathoracic leg; 39, urotergite I, left half; 40, id., detail of lateral comb; 41, id., detail of sublateral comb; 42, urotergite of mid-body segment, right half; 43, id., detail of submedial comb; 44, id., detail of sublateral comb; 45, id., detail of lateral comb; 46, urotergite VIII, right half; 47, urotergite IX, right half; 48, id., detail of infralateral setae insertions; 49, urotergite $X$ of 9 ; 50, urosternite I; 51, id., detail of medial comb; 52, urosternite $V_{\text {; }} 53$, id., detail of left submedial comb; 54, urosternite VIII; 55, id., detail of macrochaeta insertion; 56, urosternite IX and ovipositor; 57, ovipositor, detail of apical articles of anterior gonapophyses; 58, id., detail of apical articles of posterior gonapophyses; 59, urosternite IX and stylet (WAM E83518); 60, basal articles of median dorsal appendage (WAM E83514); 61, basal portion of cercus (WAM E83514). All scale bars $=0.1 \mathrm{~mm}$. 
only appears to have about five such setae), three very short stout setae on the internal face behind the molar region and a bush of about 50 setae and macrochaetae externally. Maxilla (Figures 18, 19) without special characters, the lacinia with three strong teeth, six lamellate processes and a row of five to six setae, apical article of maxillary palp (Figure 20) not long and slender, 2.0-2.8 times longer than wide and 1.07-1.43 times longer than penultimate article, tapered distally, the ultimate article in both sexes with three complex branched papillae in a longitudinal line in the apical half, one of which is very close to the apex. Labium (Figure 21) broad with a row of setae on prementum and setae across the postmentum; labial palp short, apical article (Figure 22) about as long as wide (0.81.3) with $2+3$ papillae of compact type.

Thorax: pronotum (Figure 23) with setal collar of one to three irregular rows of setae which are short and apically bifurcated (at least laterally as they are lost in the medial area of all specimens examined), lateral margins with small setae, some cilia and several apparently larger setae (only insertion points remain) plus three larger submarginal single macrochaetae (again only from size of insertion points), the more posterior two of these being associated with trichobothria; trichobothrial areas open and in contact with the lateral margins (Figure 24), the anterior trichobothrial area about half way along the margin with some small setae and cilia and the trichobothria positioned slightly anterior to the macrochaeta and closer to the margin, posterior trichobothrial area in posterior lateral corner also with small setae and cilia with one large macrochaeta and a larger seta posterior to it and away from the margin, the trichobothria located mediad to the macrochaeta; posterior margin distinctly concave with $1+1$ combs of two macrochaetae associated with three small setae or cilia, but otherwise glabrous (Figure 25). Meso and meta nota (Figures 26-29) laterally and posteriorly similar to pronotum except progressively fewer marginal setae and cilia, the anterior trichobothrial area located more posteriorly and the macrochaetae anterior to these trichobothrial areas are grouped into two small combs each of two macrochaetae with a small cilia anterior to and between the insertion points.

Presternum of prothorax short with transverse row of setae which are fairly long, robust and apically bifurcated medially, prosternum narrow cordiform (Figures 30-31) margins tapering slightly concave in distal third, surface not flat but centre folded/curved inwards between coxae, about as long as wide, distal half with many fine marginal setae and small cilia, submarginal irregular rows of six to seven stronger setae on each side (only visible as insertion points). Mesosternum (Figure 32) slightly longer than broad, not distinctly concave in distal third with a total of five to seven setae on each side, forming submarginal combs near the distal margin on each side (Figure 33). Metasternum more rounded and sometimes slightly truncate apically (Figure 34), about as wide as long, with $1+1$ distal combs each of five to six setae, the distance between them about twice the length of each comb or slightly more (Figure 35 ).

Legs (Figures 30, 32 and 36-38), tibia L/W ratio PI 2.7-3.6, PII 2.7-3.6, PIII 2.9-3.9; tarsi L/W ratio PI 3.8-6.6, PII 5.7-7.8, PIII 6.1-8.9. Coxa of prothoracic leg with external submarginal rows of strong apically bifurcate macrochaetae often in groups of two and a stout macrochaeta antedistally, small article basal to coxa with external comb of four long strong apically bifurcate macrochaetae. Trochanter with fine setae and cilia only. Femur with lanceolate scales and long fine setae as well as five very robust spines ventrally on surface away from the margin and two strong stout spines apically. Tibia with two pairs of strong stout macrochaetae on dorsal margin, ventral margin with two pairs of stout robust macrochaetae as well as longer robust setae and another strong spine subapically, surface also with fine setae and possibly a few lanceolate scales (artefact from slide preparation?); apical spine of tibia with small setae (Figure 36). Tarsus with four articles, the most distal joint almost obsolete and difficult to see. Pretarsus with robust curved outer claws and a strong, more or less straight but shorter medial claw (Figure 37). PII and PIII similar except small sclerite basal to the coxa without macrochaetae; tibia of PIII apparently without a long laterally projecting thin seta (not seen in any specimen examined in detail however a lot of setae are missing).

Abdomen: Urotergite I (Figure 39) with lateral combs of one or more usually two macrochaetae and sublateral combs of two macrochaetae, seen only as insertion points (Figures 40,41); urotergites II-VII with three pairs of combs (Figures 42-45), the lateral and sublateral combs with three macrochaetae and the submedial with a single macrochaeta, two or three much smaller setae are located between the combs and the margin and there are a few cilia around the macrochaetae; urotergite VIII (Figure 46) lacking sublateral combs; urotergite IX with two small infralateral setae (Figures 47,48), as well as a few cilia. Urotergite X (Figure 49) short parabolic, much wider at base than long, setae along lateral margins and $1+1$ presumably larger submarginal setae in the postero-lateral angles (only insertion points visible in all specimens). 


\begin{tabular}{lllll} 
Segment & Urotergite Lateral & Urotergite Sublateral & Urotergite Submedial & Urosternites \\
\hline I & $1-2$ & 2 & - & 2 (medial) \\
II & 3 & 3 & 1 & 2 \\
III & 3 & 3 & 1 & 3 \\
IV & 3 & 3 & 1 & 3 \\
V & 3 & 3 & 1 & $3-4$ \\
VI & 3 & 3 & 1 & $3-4$ \\
VII & 3 & 3 & 1 & 4 \\
VIII & 3 & - & 1 & 1 \\
IX & $0^{*}$ & - & - & -
\end{tabular}

* Two small setae and some cilia infralaterally.

Urosternite I with two medial setae, sometimes quite small (Figures 50, 51), urosternite II with 1+1 combs of two setae, urosternites III-IV with $1+1$ combs of three macrochaetae as well as one or two small thin setae, urosternites V-VII with $1+1$ combs of three to four macrochaetae (Figures 52, 53), urosternite VIII in 9 (Figures 54, 55) with $1+1$ single macrochaetae plus smaller marginal setae internally to the stylet. Genital region of $q$ as in Figure 56, the internal process of coxite IX about 1.4 times longer than wide at its base and three times longer than the external process. Ovipositor moderately long (up to 2.30 times HW), exceeding the apex the internal process of coxite IX by about 4.7 times the length of the internal process, composed of about 38 articles. Distal articles of gonapophyses VIII and IX as in Figures 57 and 58.
Stylets in two pairs in the $q$ (VIII-IX) but only one pair in the $\delta$ (IX); all stylets with at least two significantly stronger setae apically (Figures 54, 59), stylets IX more than twice as long as stylets VIII.

Terminal filaments with setae and trichobothria as shown in Figures 60 and 61.

Male: Urotergite $\mathrm{X}$ slightly shorter than in $q$ (Figure 62 cf. Figure 49); coxite IX as in Figure 63, the internal process acute, subtriangular about 3.5 times longer than the apically truncated external process and only slightly longer than broad at its base, external margin with a few moderately strong setae. Parameres small, wider than long with a few fine setae (Figure 64). Penis (Figure 65) typical for genus with numerous glandular setae apically, each set on a protuberance.
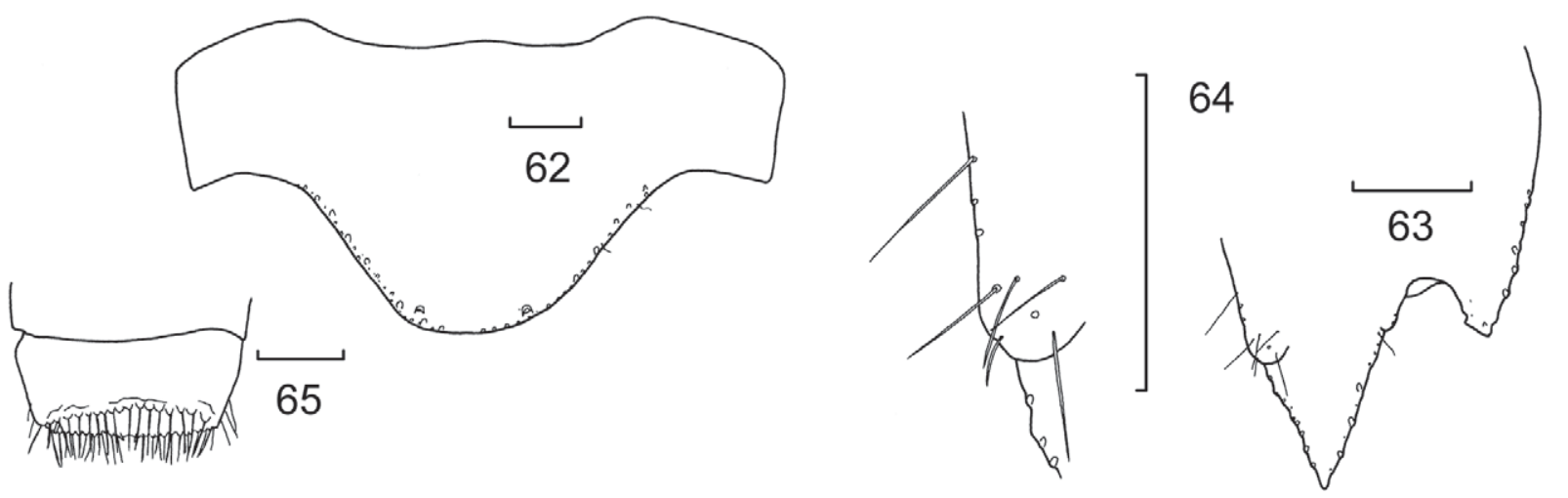

FIGURES 62-65 Heterolepisma parva sp. n. I (WAM E83510): 62, urotergite X; 63, urosternite IX; 64, id., detail of paramere; 65 , penis. All scale bars $=0.1 \mathrm{~mm}$. 


\section{ETYMOLOGY}

The specific name derives from the Latin for "small" relating to the size of this species relative to its congeners.

\section{HABITAT}

A total of about 430 Heterolepisma parva specimens were collected during four sampling periods on Barrow Island (March 2006, May 2006, Sept 2006, May 2007). They were found at 35 of the 40 sampling sites from which silverfish were collected. $55 \%$ were collected using Winkler sac sampling of leaf litter, $45 \%$ were found in pitfall traps, usually along with one to four species of Acrotelsella. Only one specimen was collected at night by hand, but no other details were available. It is probably a leaf litter dwelling species.

\section{DISCUSSION}

While clearly different to all other described species of the genus due to its small size, detailed comparison with all other species is difficult due to the generally inadequate descriptions of most species.

Mendes (pers. comm.) has suggested that there may be two groups within Heterolepisma distinguished by the presence or absence of chaetotaxy on the first urosternite. Heterolepisma parva has a small medial comb of two setae; other species with a medial comb include $H$. bisetosa (Carpenter, 1916) from the Seychelles and Somalia, H. exacta (Silvestri, 1918), H. japonica (Uchida, 1968), H. mossambicensis Mendes, 1993, H. primafra (Silvestri, 1949) from Angola, H. rouxi (Silvestri, 1915) from New Caledonia and $H$. serranoi Mendes, 2011 from Brazil. Urosternite I is reported as glabrous in $H$. annectans (Silvestri, 1924) from the Juan Fernandez Islands and known to be glabrous in several other species present in Eastern Australia. It is probably glabrous in the following species where the authors describe chaetotaxy only on segments II-VII or VIII without specifically stating that urosternite I is glabrous- $H$. dispar Uchida, 1944 from Japan, H. horni Stach, 1933 from Ecuador, H. howensis Womersley from Lord Howe Island, H. insularis (Banks, 1901) from the Galapagos Islands, H. kraepelini, H. michaelseni and H. stilivarians all described by Silvestri (1908) from Western Australia. This character state has been inadequately reported for $H$. pampeana (Silvestri) and $H$. andina (Silvestri) and H. trisetosa (Escherich) from Brazil and Indonesia (but now considered as species inquirenda (Mendes 2011)) and H. zealandica (Tillyard).

In contrast to many species that have $1+1$ sublateral single macrochaetae on the urosternites,
H. parva has small combs of macrochaetae (usually three to four) in the same position. This character, generally more reliably described, is shared with $H$. pampeana (probably), H. andina, H. dispar, $H$. insularis, H. japonica, H. kraepelini, H. michaelseni, H. primafra and $H$. rouxi; the character state in $H$. zealandica is uncertain.

The chaetotaxy of urotergite I is also of use to distinguish species although it may not be that useful in distinguishing higher level relationships. Heterolepisma parva lacks the submedial combs on urotergite $\mathrm{I}$, thus only displaying $2+2$ combs. This is also the case with $H$. exacta, $H$. horni, $H$. howensis, $H$. japonica, $H$. mossambicensis and H. bisetosa (although rare individuals of $H$. bisetosa are also reported to display $3+3$ combs). Heterolepisma primafra only displays $1+1$ combs on this urotergite, while several species have $3+3$ combs $(H$. pampeana, $H$. andina, $H$. dispar, $H$. insularis, $H$. rouxi and $H$. serranoi). This feature is also somewhat overlooked in earlier descriptions and this character state is not described for $H$. annectans, $H$. kraepelini, $H$. michaelseni, $H$. stilivarians, $H$. trisetosa and $H$. zealandica.

The number of abdominal stylets is also often used to separate species but its value for higher level taxonomy is questionable and one Australian species ( $H$. stilivarians) is reported to be quite variable in the number of stylets presented (from 3 to 5 pairs of stylets). Heterolepisma parva has 2 pairs of stylets on the female and just one on the male, an arrangement usually adequately reported and shared with just $H$. dispar, $H$. michaelseni, and $H$. primafra.

Heterolepisma parva can be distinguished from all other described species using the above combination of characters, perhaps being closest to $H$. japonica with which it shares the first three characters, but differs in the number of stylets. It is also smaller than $H$. japonica, with shorter abdominal combs and only $2+2$ combs on urotergite VIII.

Heterolepisma parva also differs from many other species by the presence of lanceolate scales on the femora and clypeus. These scales can be very easy to overlook and so may also be present on more species than is currently recorded. Similar scales have been reported for $H$. bisetosa, $H$. horni and $H$. serranoi.

This genus is very well represented in Australia, especially in the cooler, and often less arid regions and most of the material collected cannot be assigned to a described species with any confidence. Given that silverfish are only rarely the focus of collection efforts but are nevertheless known to occur throughout much of the southern hemisphere including many oceanic islands, it is likely that this will be a very large genus and one clearly in need of much work. 


\section{ACKNOWLEDGEMENTS}

I would like to thank Professor Jonathon Majer, Dr Nihara Gunawardene, Dr Shae Callan and the Curtin University team for the supply of the material and the funding of a microscope. I would also like to thank Dr J. Irish, Namibia for sharing his notes on the Australian silverfish fauna with me and Dr Luis Mendes of the Instituto de Investigação Científica Tropical, Lisbon, Portugal for providing some of the literature and his on-going advice.

\section{REFERENCES}

Banks, N. (1901). Thysanura and Termitidae. Papers from the Hopkins Stanford Galapagos Expedition 18981899. V. Entomological Results 5. Proceedings of the Washington Academy of Sciences 3: 541-546.

Callan, S.K., Majer, J.D., Edwards, K. and Moro, D. (2011). Documenting the terrestrial invertebrate fauna of Barrow Island, Western Australia. Australian Journal of Entomology 50(4): 323-343.

Carpenter, G.H. (1916). I. The Apterygota of the Seychelles. Proceedings of the Royal Irish Academy. Section B 33: 1-70.

Escherich, K. (1905). Das System der Lepismatiden. Zoologica (Stuttgart) 43: 1-164.

Irish, J. (1990). Phylogeny of the Lepismatidae (Thysanura), with a revision of the southern African genera. Unpublished Ph.D. thesis, Faculty of Science, University of Pretoria. $337 \mathrm{pp}$.

Laibach, E. (1952). Lepisma saccharina L., das Silberfischchen. Zeitschrift für hygienishe Zoologie und Schädlingsbekämpfung 40: 321-370.

Mendes, L.F. (1991). 1.1. On the phylogeny of the genera of Lepismatidae (Insecta: Zygentoma). pp. 3-13 in Veeresh, G.K., Rajagopal, D. \& Viraktamath, C.A. (eds) Advances in management and conservation of soil fauna. New Delhi Bombay Calcutta: Oxford \& IBH Publishing Co. Pvt. Ltd.

Mendes, L.F. (1993). Novos dados e descrições de Zygentoma (Insecta: Apterygota) africanos. Garcia de Orta, Séries Zoologia, Lisboa 19(1-2): 91-105.

Mendes, L.F. (2011). On some Zygentoma (Insecta) from Brazil with description of one new species of the genus Heterolepisma Escherich, 1905 (Lepismatidae). Boletin Sociedad Entomológica Aragonesa 48: 67-72.

Paclt, J. (1967). Thysanura. Fam. Lepidotrichidae, Maindroniidae, Lepismatidae. Genera Insectorum 218e: $1-86$.

Silvestri, F. (1902). Materiali per lo studio dei Tisanuri. I-V. Bollettino della Società Entomologica Italiana 33: 204-249.

Silvestri, F. (1908). Thysanura. in Michaelsen, W. \&
Hartmeyer, R. (eds) Die Fauna Südwest-Australiens. Ergebnisse der Hamburger südwestaustralischen Forschungsreise 1905 2: 47-68 Jena: Gustav Fischer.

Silvestri, F. (1915). Thysanura della Nuova-Caledonia e delle isole Loyalty. in F. Sarasin and J. Roux (eds) Nova Caledonia (A). Forschungen in Neu-Caledonien und auf den Loyalty Inseln (Recherches Scientifiques en Nouvelle Caledonie et aux Iles Loyalty 1913-1926) 2: 75-81 Wiesbaden.

Silvestri, F, (1918). Thysanura. in L. Lhomme (ed.) Voyage de Ch. Allaud et R. Jeannel en Afrique orientale (19111912). Résultats scientifiques, Apterygogenea I: 1-28 Paris: Librarie des Sciences naturelles.

Silvestri, F. (1924). Thysanura et Embioptera. in Skottsberg (ed.) The Natural History of Juan Fernandez and Easter Island 3(3): 325-328 Uppsala.

Silvestri, F. (1949). Insecta Thysanura hucusque in Lunda reperta. Publicações culturais da Companhia dos Diamantes de Angola 6: 61-84.

Stach, J. (1933). Heterolepisma horni n.sp. und die Zusammenstellung der Arten der Gattung Heterolepisma (Thysanura). Annales Musei Zoologici Polonici, Warszawa 9(22): 341-350 and Table XLVII.

Tillyard, R.J. (1924). Primitive wingless insects. Part I. The silverfish, bristletails and their allies (Order Thysanura). New Zealand Journal of Science and Technology 7: 232-242.

Uchida, H. (1944). Die Bestätigung der nicht bescriebenen Art, Heterolepisma dispar Silv. (Thysanura). Annotationes Zoologicae Japonenses 22(4): 185-189.

Uchida, H. (1968). Two new species of Lepismatidae from South East Asia, with a revision of Japanese Atelura. Mushi 42(1): 1-9.

Womersley, H. (1939). Primitive insects of South Australia. Silverfish, springtails and their allies. Adelaide : Frank Trigg, Government Printer 322 pp.

Womersley, H. (1942). A new species of silver-fish from Lord Howe Island. Records of the Australian Museum 21: 116-117.

Wygodzinsky, P. (1961). Synonymical notes on the Lepismatidae (Thysanura). Pan-Pacific Entomologist 37(4): 213-216.

Wygodzinsky, P. (1967). On the geographical distribution of the South American Microcoryphia and Thysanura (Insecta). in Debouttville, D. \& Rapoport, E. (eds) Biologie de L'Amérique Australe 3: 505-524 Paris: Centre National de la Recherche Scientifique.

MANUSCRIPT RECEIVED 31 AUGUST 2012; ACCEPTED 5 FEBRUARY 2013. 